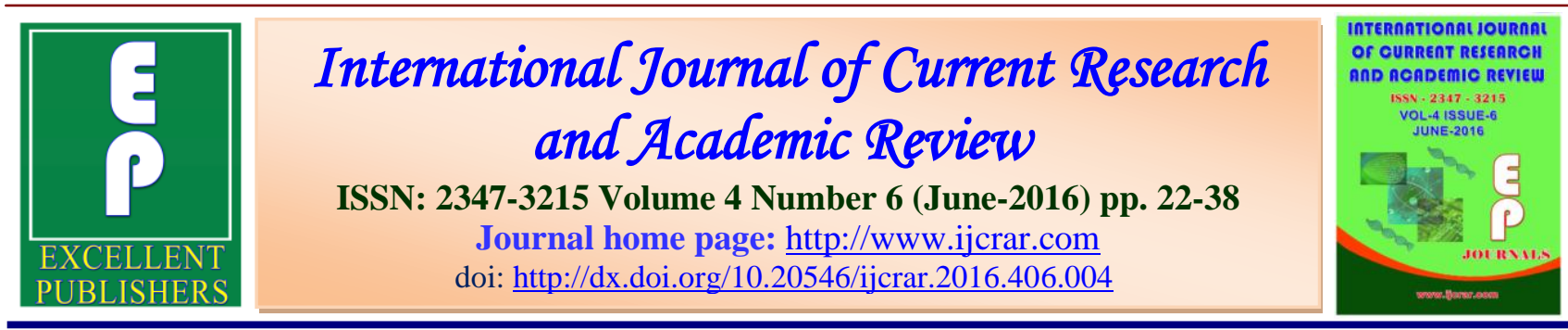

\title{
Stock Profile of Hilsa Shad Population in Bay of Bengal Region- A Review
}

\section{Utpal Bhaumik*}

Former Head of Division, Central Inland Fisheries Research Institute, Barrackpore, West Bengal, India

*Corresponding author

\section{KEYWORDS}

Race,

Cluster,

Morphometric,

Meristic,

Phylogenetic,

Allozyme,

Single stock
A B S T R A C T

Hilsa shad, also known as Indian shad, migrates to freshwater environment of the River systems for breeding and thereafter, nourishment of the young ones. Hilsa populations of different rivers are distinct and may be distinguished from one another by morphometric, serological and meristic characters. There is controversy regarding stocks or races of Hilsa in different water bodies of Bangladesh. Genetic and otolith data both showed that Hilsa from India Myanmar were not significantly different from the fish collected from coastal areas of Bangladesh, and suggest that fresh water environment of the River systems for breeding and thereafter, nourishment of the young ones. Most of the stocks of Hilsa are anadromous, breeding much above tidal limits. Some stocks have also been reported to remain permanently in the freshwater stretch of Rivers. The Hilsa shad is largely an anadromous species, but two other ecotypes - a fluvial potamodromous type and a marine type - have been recognised. The possibility of existence of different races of Hilsa was expressed by many workers. Some studies indicated that Hilsa populations of different rivers are distinct and may be distinguished from one another by mo Hilsa in the Bay of Bengal were a single stock. In Pakistan only one homogenous population of Hilsa ascends the river Indus. In Pakistan only one homogenous population of Hilsa ascends the river Indus. Phylogenetic analysis revealed that the Hilsa from Bay of Bengal origin and Arabian Sea origin formed two distinct different clusters. However, proper measures are very much warranted towards conservation the stocks for sustainable management of Hilsa fishery in Bay of Bengal region.

\section{Introduction}

The Hilsa shad (Tenualosa ilisha) occurs in foreshore areas, estuaries, brackish-water lakes and freshwater rivers of the western division of the Indo-Pacific region. Its marine distribution extends from Iran and
Iraq in the Persian Gulf to the west coast of India in the Arabian Sea and the Bay of Bengal (Pillay and Rosa, 1963). Hilsa shad, also known as Indian shad, migrates to freshwater environment of the River systems 
for breeding and thereafter, nourishment of the young ones. The breeding success of species depends on synchronous effect of eco-environmental and biological conditions (Bhaumik and Sharma, 2012). Hilsa moves on the surface in the foreshore region whereas in the River they move in deeper zones near the bottom. Generally the peak upstream migration of Hilsa in the Rivers takes place during the South-West monsoon. The fish normally inhabits the lower region of the estuaries and the foreshore areas of the sea. Hilsa prefers to reside in this region due to the presence of sub-surface oxygen, relatively low salinity, strong tidal action, high turbidity, heavy siltation and rich growth of plankton (Pillay and Rosa, 1963). Most of the stocks of Hilsa are anadromous, breeding much above tidal limits (Naidu, 1939). Some stocks have also been reported to remain permanently in the freshwater stretch of Rivers (Hora, 1938, Hora \& Nair, $1940 \mathrm{a}$ and b) and some spawn in tidal areas. There is no doubt that Hilsa is very salinity tolerant and inhabits freshwater, estuarine and coastal waters in the Bay of Bengal. The paper deals with review of studies made by the scientists across the globe with a view to throwing some light on the stock or race of migratory population of Hilsa in the waters of Bay of Bengal region.

\section{Taxonomy}

The taxonomy of the species, described below, is based on the studies of Pillay and Rosa (1963), Fischer and Whitehead (1974), Whitehead (1985), Shad Foundation (1998), Rahman (2001), FishBase (2012), EOL (2012) and Rahman et al.,2012.

\section{Systematic Position}

Phylum: Vertebrata; Sub-phylum: Craniata; Superclass: Gnathostomata; Series: Pisces;

Class: Teleostomi; Sub-class: Actinopterygii
Order: Clupeiformes; Sub-order: Clupeoidei Family: Clupeidae; Sub-family: Alosinae Genus: Alosa

Species: A. sapidissima, A. aestivalis, A. agone, A. alabamae, A. algeriensis, A. alosa, A. immaculata, A. braschnikowi, A. maeotica, A. saposchnikowii, A. chrysochloris, A. mediocris,A. fallax, A. kessleri, A. killarnensis, A. macedonica, A. pseudoharengus, A. caspia, A. sphaerocephala, A. suworowi, A. tanaica, A.vistonica, A. volgensis, A. pontica and A. curensis

Genus: Hilsa

Species: Hilsa kelee

Genus: Tenualosa

Species:Tenualosa ilisha (Hamilton, 1822)

Tenualosa macrura (Bleeker, 1852)

Tenualosa reevesii (Richardson, 1846)

Tenualosa thibaudeaui (Durand, 1940)

Tenualosa toli (Valenciennes, 1847)

\section{Comparative Identifying Characteristics}

Maximum in Tenualosa toli compared to other two species (Fig.1). The important morphometric Comparative characters are depicted below for smooth identification of Tenualosa ilisha. Size of the head is largest for Hilsa kelee followed by Tenualosa toli and Tenualosa ilisha whereas caudal and fork lengths were variables between the species have been presented in Table 1 .

The Hilsa shad is largely an anadromous species, but two other ecotypes - a fluvial potamodromous type and a marine type have been recognised. The potamodromous stocks appear to remain in the middle reaches of the rivers throughout the year and breed therein. The anadromous stocks, whose normal habitat is the lower region of the estuaries and the foreshore areas, ascend the rivers during the breeding season and return to the original habitat after spawning 
(Raja, 1985; Bhaumik et al., 2011).). The upstream migration during the main breeding season depends largely on the commencement of the south-west monsoon and consequent flooding of the major rivers of Bangladesh, Burma and India.. However, it is not known whether migratory populations mix during migration or whether they pass each other spatially and temporally. Therefore, the knowledge on the exact stocks is still not clear.

\section{Geographical Distribution of Hilsa}

\section{Marine Habitat}

Distribution of the species in the marine zone coincides with the Indian monsoon region (Northern part of Indian Ocean) and ranges from the Persian Gulf to South-Vietnam, including the Bay of Bengal, proceeding to the Java and the South China Sea, the coasts of Indian Ocean, the Persian Gulf, the Gulf of Tongking, the Arabian Sea, the Gulf of Oman, the Gulf of Aden, south to Durban, Madagascar and some coastal waters of Sri Lanka and Laos (Figure. 2). In the Persian Gulf, the distribution is mainly concentrated in the marine waters of Iran and Iraq. In the Arabian Sea, the species is concentrated in the West coast of India from the Gulf of Cutch along the Saurashtra coast, the Bombay coast, the foreshore areas near the mouths of the Narbada and the Ulhas rivers, and is occasionally found along the Malabar (Kerala) coast. In the East coast of Bay of Bengal, fish concentrate in Indian region of Chennai coast, the Kakinada coast, the Visakhapatanam coast (Andhra Pradesh), the Chandipore (Balasore, Orissa) coast, the Sagar and Digha (West Bengal) coast, in the marine waters of Bangladesh, especially in and around the Meghna estuary region and along the inshore region of Myanmar down to the Mergui Archipelago. In fact, the species is mainly concentrate in the Bay of
Bengal, especially in the territorial waters of Bangladesh, India, Pakistan and Myanmar (Rahaman et al., 2012).

\section{Estuarine and Freshwater Habitat}

Adult Hilsa migrates from saline water to estuarine and fresh waters mainly for spawning purposes. In Bangladesh Hilsa is widely distributed in coastal areas, estuaries and rivers mainly the Padma, Meghna, Jamuna and other deltaic rivers and their major tributaries and distributaries. In India, it is mainly distributed in the lower reaches of the rivers Hooghly, Mahanadi, Godavari, Narbada, Tapti and their estuaries, and also in Chilika Lake. In Myanmar it is mainly found at the lower region of the rivers Irrawaddy, Sittang and Naaf. In Pakistan the most important river is the Sind (Indus), Jhelum and Ravi (Jafri, 1988).

Stock or Race of Hilsa population in the Bay of Bengal Region

The possibility of existence of different races of Hilsa was expressed by many workers. Some studies indicated that Hilsa populations of different rivers are distinct and may be distinguished from one another by morphometric, serological and meristic characters Raja (198).

Day (1873) mentioned two classes which ascend the rivers: those below one year age and which do not appear to breed, or if they do so, it is at the very end of the year or commencement of the succeeding one; and those which breed at commencement of or during the monsoon. His observations thus indicate two racial population of Hilsa. Thus, possibility of there being different races of Hilsa in the Gangetic system of rivers was conceived at a very early stage of investigations. Naidu (1939) also pointed out the variations in the number of lateral 
blotches and the absence of them in some, and has raised the question whether these variations distinguish distinct races or species or whether these are only a variation of colouration in the same species. He also opined that there is no sufficient evidence to prove that that fish juvenile known as "Jatka" in East Bengal (presently Bangladseh) is really the young Hilsa and that the likelyhood of their being different stocks has to be investigated. Quddus et al., (1984) confirmed the identity of Jatka as the juvenile of Hilsa. Rahaman and Naevdal (1998) studied the "Jatka" to verify whether it is to be considered as the offspring of Hilsa. The study depicted evidence that "Jatka" is the progeny of anadromous Hilsa in inland rivers of Bangladesh through closer understanding of protein electrophoresis and isoelectric focussing to reveal genotypes and genotype distribution. Jenkins (1938) questioned that whether two or more races or varieties of Hilsa exist with different spawning grounds and habits.

Job, T.J., (1940) wondered whether Hilsa which spawn in Sunderbans and which spawn in the Ganga beyond Monghyr represent distinct races and if so, whether they could be distinguished apart. Mojumder (1939) indicated that there are differences between the Hilsa occurring in different rivers of East Bengal (presently Bangladesh) and also in the sea. He recognised three categories of Hilsa: (1) those of the saline water of the seas, (2) those from the muddy freshwater of the rivers like Padma or Hooghly, (3) those from the clear freshwater of the river like Meghna, though some may migrate from place to place with the rise of water. According to him, Padma Hilsa are thicker in structure and of bright silvery colour while the Meghna Hilsa are thinner, a bit darker and a bit elongated. He further inferred that turbidity and the degree of salinity are factors separating the stocks of Hilsa. Dutt (1966) opined that there is possibility of three eco-types of Hilsa population.

Pillay (1957) noticed that Hilsa caught during September-October, 1955 in the Hooghly estuary possessed a relatively deeper body, compared to the Hilsa samples collected during 1952 and 1953. Thus, the author inferred that the fish caught in 1955 presented a stock different from the one that usually ascends the river. Ghosh (1967) while examining the fishing of Hilsa fish at Allahabad suggested that the stocks of Hilsa at Allahabad are heterogenous in nature and the Jamuna stock is endemic, probably heterogenous and is supplemented by a migratory stock. He further indicated that the different stocks identified by Pillay et al. (1963) in the upper Ganga, may perhaps be the Jamuna stock with small range of migration within the local waters.

Hora (1940) suggested that Hilsa of Hooghly and East Bengal (presently Bangladesh) might represent separate stocks. Pillay (1952) from preliminary biometric study showed that there are probably two stocks in the area. Pillay (1954 and 1955) studied morphological and physiological characteristics of blood of Hilsa of the Hooghly and recognised three blood groups among the fishes. Sujansinghani (1955) observed significant differences between length - weight relationship of Hilsa samples for the estuary of Orissa and Hooghly.

The Hilsa population in the river Hooghly, Ganga-Padma, Brahmaputra, Barak, Godavari, Krisha, Cauvery and Narmada, Chilika lake and the Saurashtra coast differ significantly from one another (Pillay et al., 1963). They also interpreted that the Ganga has at least two populations of Hilsa which 
are different from the population of the Padma. Hora and Nair (1946) observed no supportive evidence exists regarding possibilities of two or more races as far as stocks of Hooghly and those obtained for the Ganga at Allahabad. The stock of Padma river can be distinguished from the others by the low average number of vertebrate with duplicate neural spines.

During the investigation of Hilsa stocks of India, Pakistan and Burma, the Hilsa Subcommittee the IPFC observed that whilst it is most likely that the western populations of the Persian Gulf and the Indus remained quite distinct from those of the western population of the Persian gulf and of the Indus remained quite distinct from those of the Bay of Bengal, the status of the Bay Bengal stocks cannot be considered with the same assurance ; there is possibility that each separate river system has its own stock and than even each of these is further fragmented into spawning or ecological groups: there is also possibility of communication between at least the stocks of the rivers flowing into the Bay of Bengal (Hora,1952).In view of the interest thus generated, the subject engaged detailed study in the subsequence years.(Pillay,1952;1954 and 1957; Pillay and Ghosh,1962; Ghosh et al.,1968; Rao 1969: Ramakrishnaiah,1972; Quddus,1982).

Pillay (1952 and 1954) made a preliminary study comparing the data relating to body size and length of head of samples drawn from what was East Pakistan (Bangladesh), West Bengal, Uttar Pradesh and Orissa, and indicated the possibility of there being at least three stocks of Hilsa distinguishable by the relative size of the body, one stock coextensive from East Pakistan (Bangladesh) through West Bengal to Orissa coast, another from east Pakistan (Bangladesh) and Orissa and a third from Uttar Pradesh.
Pillay (1957) is his morphometeric study of the Hilsa populated of the Hooghly and Chilika lake, considered the number of scutes, number of lateral line scales and the number of vertebrate from the meristic side, and among the non-meristic character, fork length, standard length, height of the body, length of head, diameter of eye length, height and thickness of caudal peduncle, and thickness of body. The study was undertaken to determine the monsoon and winter runs of Hilsa in the Hooghly bear on two different stocks. He concluded that they constituted a single stock and only distinguishable difference is in the age composition of fish in the runs. These observations are at variance with those expressed by him earlier (Pillay, 1957). His study also indicated that the Hilsa of Chilika lake belong to stock separate from that of the Hooghly.

Pillay (1957), Pillay and Ghosh (1963) made a comparison of regression and $\mathrm{D}^{2}$ analysis of body measurement as well as comparison of vertebral counts of the sample from the rivers Hooghly,Ganga, Padma, Brahmaputra, Barak, Godavari, Krishna, Cauvery and Narmada, the Chilika lake and the Saurashtra coast. The non-meristic characters include the total length, standard length, fork length, standard length, height of the body, length of head, diameter of eye length, height and thickness of caudal peduncle, and thickness of body. The result indicated that the different major river systems, the Chilika lake and Saurashtra coast have their own stock of Hilsa and there is very little, if any, intermingling among them. The river ganga has at least two population represented by same studies from Allahabad and Buxar. The stocks of Ganga, Padma, Chilika lake, Godavari, Saurashtra coast could be distinguished from the Hilsa of Hooghly by the regression of one or the other body measurements of total 
length. The height of the body, length of head, length, height and thickness of caudal peduncle, thickness of body and diameter of eye length, were found to be relatively more useful in the identification of stocks. With the total no of vertebrate, some on the basis of average no of trunk vertebrate, some of the average number of caudal vertebrate and some by average no of vertebrate with duplicate neural spines.

Ghosh et al. (1968) examined samples from six centers in the Gangetic system covering the rivers Ganga and Padma. Samples were drawn from non-selective gear and their study was based on statistical analysis of tie head length, height at the original of dorsal fin and at the original anal fin in relation to the total length. They could distinguish on the basis of the body, three forms 'slender', 'broad', and 'broader', Employing the method of discriminate score, the distribution of : individual subpopulations in the Gangetic system was studied.They concluded that all the three sub-populations are widely distributed in the entire stretch from Allahabad on the Ganga, to Lalgola on the Padma in the downstream, However, the limited number of observations did not permit the authors an understanding of the pattern and the rate of intermingling of the sub-populations between different sectors. They were also of the opinion that it is likely that each sub-population may occupy a separate spawning ground and, therefore, at the spawning season the intermingling would be negligible, or absent. That the population at a center need not be homogeneous was also brought to light by then investigations and in this context they had pointed out that the heterogeneity of the Hilsa population at a centre was overlooked in the investigations of Pillay et al. (1963), The authors' data on distribution of individual sub-populations also indicate an interesting sequence of the importance shifting from one variety to the other, from west to east of the Investigation area. It is seen that the dominant 'broad' forms of Allahabad are replaced by the 'broader' forms at Varanasi and Buxar, which are localities located east of Allahabad, The' Slender' form dominates at Bagalpur, and is replaced by the 'broad' forms at Rajmahal, which in turn, is replaced by the 'broader' type at Lalgola on river Padma. The significance of such a distribution is not clear. Another interesting feature is that between Bhagalpur and Lalgola - a distance of about $100 \mathrm{~km}$ along the river-each of the three varieties has dominated at each of the three centers in the same monsoon season of 1964, This would probably support the authors' contention that each sub-population may occupy a separate spawning ground and the intermingling during the spawning season could be negligible or absent. However, the findings on existence of three sub population viz. "Broad", "Broader" and "Slender" in the Ganga river system during pre-Farakka barrage period (Ghosh et al., 1968) have been contradicted by many authors (Gupta,1987) as they have found a homogeneous population of Hilsa in the same water bodies. It is also identified that certain variety of Hilsa has a definite season and extent of ascending migration for spawning. Particularly spawning of "Slender" variety Hilsa in the lower Ganga is restricted only to winter season (Ghosh and Nangpal, 1968). While the monsoon and winter runs of Hilsa observed in the Hooghly estuary belonged to the same population, the only difference observed was being in their size composition (Pillay, 1958).

With regard to the Chilika population, Jhingran and Natarajan (1966) observed that winter/ spring and monsoon samples did not indicate any significant differences between these two migrant populations, 
suggesting thereby their homogeneity. Ramakrishnaiah (1972) who subjected his data on the number of scutes and vertebrae to statistical test came to the same conclusion that the monsoon and winter/spring stocks of the lake are homogeneous.

Rao (1969) examined the juveniles of different centers on the Godavari estuary and took into consideration the meristic data on pectoral fin rays, ventral scutes, and vertebrae and morphometric data on standard length, height of the body and head length. He found significant differences between the year classes in respect of the number of pectoral fin rays and number of vertebrae. Significant differences were also seen in height as well as head length.

There is controversy regarding stocks or races of Hilsa in different water bodies of Bangladesh (Rahaman, 2006). Some workers (Ahmed, 1961 and Das et al., 1987) observed homogeneous stock of Hilsa population in Bangladesh waters whereas some others (Quddus, et al.1984, Rahaman and Moula, 1992, Rahaman et al.1997) have found heterogeneity among Hilsa in different water bodies. Qureshi (1968) has briefly mentioned, without the support of data, that the biometric data study conducted in East Pakistan (Bangladesh) indicated homogeneity of stocks. Biometric analyses carried out by Safi et al., 1977, studied the samples of Hilsa collected fom the rivers namely Padma, Meghna, Jamuna and Dhaleswari of Bangladesh. Owing to their distinctive differences in the body height, he differentiated the species as "Broad type "and "Slender type ". He employed, for comparison, 15 meristic and 8 morphpmetric characters to unravel the racial characteristics of Hilsa of these rivers. Of these meristic characteristics, significant differences were observed between the two types in six number of ventral scutes, postpelvic scutes, pectoral fin rays, abdominal vertebrae with haemal arch, caudal vertebrae and number of vertebrae from the tip of vertebral column to the vertebrae with enlarged haemal arch. Among the morphometric characters, seven out of eight characters depicted significant differences. Quddus (1982), besides morphometric study of Hilsa of two types, also examined the differences in biological features. He observed that the two types have different seasons- the broad ones spawn during monsoon and the slender ones during winter. The broad types grew faster and attained greater length at each age as compared to the slender type. Fecundity estimate was considerably lower in case of the slender type. He also observed that that the broad type was characterised by silvery body, the lateral blotches disappearing in larger specimens, fins particularly dorsal and caudal were comparatively short, intermuscular bones were few in number, head tapering, head skin soft, eyes small, length of pyloric-caecum short and fat content was high. In the slender variety, the colour was reported as greenish, the blotches remain in older specimens, the dorsal and caudal fins were comparatively larger, inter-muscular bones were numerous in number, head was big in size and shape, head skin hard and eyes were large, length of pyloric-caecum large and fat content was low. Based on these observations, he opined that population in Bangladesh waters consists of two sub-species of Hilsa (Tenualosa) ilisha. Of course, he suggested for further studies to draw the final inference in this regard.

Melvin (1984) was of opinion that the large concentration of Hilsa in the Bay of Bengal may be indigenous to the rivers of Bangladesh or that they may represent a heterogeneous stock of Hilsa from many 
rivers of India, Bangladesh and Myanmar. In the later case, the respective stocks may be returning to their natal rivers for spawning.

The knowledge of genetic background of a species and its population structure is crucial for success in breeding, management, and conservation programmes in fisheries. An allozyme marker based study, using the Hilsa samples collected during the spawning period in the Ganges at five riverine locations (Brahmaputra, Padma, Ganga, Hooghly and Feeder canal), identified 26 loci encoding 15 enzyme systems, of which 13 loci were found to be polymorphic, (Lal et al., 2004). In this study, the sample from different locations did not exhibit significant genetic heterogeneity, indicating the genetic variations in the Hilsa populations were not affected and that there was only one overall panmictic (random mating) population in the Gangetic river systems.

The populations of Hilsa from different locations in rivers Ganga (Beniagram and Lalgola), Yamuna (Allahabad), Hooghly (Nawabganj), Bhagirathi (Feeder canal) and Narmada were analyzed using RAPD (Brahmane et al., 2006). The UPGMA dendrogram based on Nei's (1978) genetic distance indicated the segregation of the Tenualosa ilisha populations into two clusters. The populations from Allahabad, Beniagram, and Lalgola from Jamuna and the Ganga formed one cluster and the other cluster formed the populations from Feeder canal, Nawabgunj on the rivers HooghlyBhagirathi and Bhadbhut from the river Narmada. In another study, Brahmane (2008) studied the population genetic structure of Hilsa in India using mitochondrial DNA Cytochrome $b$ gene nucleotide sequence analysis. The study indicated that there was a free flow of gene pool and mixing of Hilsa in between the Ganga and Hooghly rivers. Further, the study revealed that the populations of river Ganga and Hooghly are observed to belong to a single gene pool and every individual Hilsa from Ganga population has an equal chance of mating with the individuals of Hooghly population. He further stated that Hilsa from Ganga-Meghna-Brahmaputra is biologically similar to that of the HooghlyBhagirathi system. Gene flow among basic genetic units is so extensive that the entire species in Bay of Bengal region behaves as a single panmictic population and there is no reproductive isolation that can result in genetic divergence.

Rahaman and Naevdal (2000) reported 5 polymorphic loci in Hilsa samples collected from Chandpur region (Lower and upper Meghna and Dhaleswari river), Barguna region (Paira, Bishkhali and Patharghata coast), and the Bay of Bengal (Cox's Bazar and Chittagong coast). Significant heterogeneity was observed between Chandpur-Cox's Bazar and Barguna-Cox's Bazar population pairs, but no heterogeneity was observed between Chandpur and Barguna population pair.Therefore, they concluded that there were two gene pools of Hilsa in Bangladesh waters. These results were in contrast with Dahle et al. (1997), who claimed that that there were three discriminating populations of Hilsa in Bangladesh waters such as (Meghna river), Barguna (Brackish water and estuarine water ) and Cox's Bazar (Sea water).

Salini et al. (2004) reported 5 interpretable polymorphic loci using sample collected from 9 sites within Bangladesh, no significant difference in allele frequencies observed within Bangladesh or within Bay of Bengal (India and Myanmar) the population was expected to be panmictric. However, they found significant difference in allele frequencies when compared with those of Kuwait and Indonesian samples, 
Int.J.Curr.Res.Aca.Rev.2016; 4(6): 22-38

indicating presence of genetically distinct population in Bangladesh, Kuwait and Indonesian waters. In the same study, Indonesian and Indian Hilsa more difference in meristic and morphometric characters than Kuwait, but Hilsa from Bangladesh could not be accurately classified.

Table.1 Comparative morphometry of three Tenualosa species

\begin{tabular}{|c|c|c|c|}
\hline Attributes & Hilsa kelee (Cuv. 1829) & Tenualosa ilisha (Ham. 1822) & Tenualosa toli (Val.1847) \\
\hline $\begin{array}{l}\text { General body } \\
\text { profile }\end{array}$ & $\begin{array}{l}\text { Body strongly compressed; } \\
\text { ventral profile more arched } \\
\text { than the dorsal profile }\end{array}$ & $\begin{array}{l}\text { Body fusiform; both dorsal and } \\
\text { ventral profiles almost equally } \\
\text { arched }\end{array}$ & $\begin{array}{l}\text { Body fusiform; ventral profile more } \\
\text { arched than the dorsal profile }\end{array}$ \\
\hline $\begin{array}{l}\text { Upper jaw } \\
\text { profile }\end{array}$ & $\begin{array}{l}\text { Upper jaw with a distinct } \\
\text { median notch when seen from } \\
\text { the front }\end{array}$ & $\begin{array}{l}\text { Upper jaw with a distinct } \\
\text { median notch when seen from } \\
\text { the front }\end{array}$ & $\begin{array}{l}\text { Upper jaw with a distinct median } \\
\text { notch when seen from the front }\end{array}$ \\
\hline $\begin{array}{l}\text { Dorsal profile } \\
\text { of head }\end{array}$ & $\begin{array}{l}\text { Fronto-parietal striae on top of } \\
\text { head exposed and numerous } \\
\text { (about } 8-14 \text { ) }\end{array}$ & $\begin{array}{l}\text { Fronto-parietal striae on the } \\
\text { head not exposed (embedded } \\
\text { in the skin) }\end{array}$ & $\begin{array}{l}\text { Fronto-parietal striae on the head } \\
\text { not exposed (embedded in the skin) }\end{array}$ \\
\hline Body depth & $30-40 \%$ of standard length & $27-32 \%$ of standard length & $30-35 \%$ of standard length \\
\hline Belly scutes & $\begin{array}{l}27-31 \text { ( } 15 \text { to } 17 \text { pre-pelvic } \\
\text { and } 12-14 \text { post-pelvic) }\end{array}$ & $\begin{array}{l}29-34 \text { (16 to } 18 \text { pre-pelvic } \\
\text { and } 13 \text { to } 16 \text { post-pelvic) }\end{array}$ & $\begin{array}{l}28-31 \text { ( } 17 \text { to } 18 \text { pre-pelvic and } 11 \\
\text { to } 13 \text { post-pelvic) }\end{array}$ \\
\hline $\begin{array}{l}\text { Dorsal fin } \\
\text { origin }\end{array}$ & $\begin{array}{l}\text { Slightly before the midpoint of } \\
\text { body }\end{array}$ & At the midpoint of body & $\begin{array}{l}\text { Slightly before the midpoint of } \\
\text { body }\end{array}$ \\
\hline Body scales & Perforated & Not perforated & Not perforated \\
\hline Axillary scales & Present on pelvic fins only & $\begin{array}{l}\text { Present on both pectoral and } \\
\text { pelvic fins }\end{array}$ & $\begin{array}{l}\text { Present on both pectoral and pelvic } \\
\text { fins }\end{array}$ \\
\hline Gill rakers & $\begin{array}{l}\text { Very fine; about } 100-150 \text { on } \\
\text { the lower arm of the first gill } \\
\text { arch }\end{array}$ & $\begin{array}{l}\text { Very fine; about } 120-250 \text { on } \\
\text { the lower arm of the first gill } \\
\text { arch }\end{array}$ & $\begin{array}{l}\text { Fine; about } 120-250 \text { on the lower } \\
\text { arm of the first gill arch }\end{array}$ \\
\hline Caudal fin & $\begin{array}{l}\text { Slightly shorter than head } \\
\text { length }\end{array}$ & $\begin{array}{l}\text { Almost the same length as that } \\
\text { of head }\end{array}$ & Larger than the length of head \\
\hline Colouration & $\begin{array}{l}\text { Blue/green on the back and } \\
\text { flanks silvery. A black spot on } \\
\text { the operculum followed by a } \\
\text { series of similar spots along the } \\
\text { flanks. Tips of anterior dorsal } \\
\text { fin rays dusky, caudal fin tips } \\
\text { also dusky }\end{array}$ & $\begin{array}{l}\text { Body silvery; a dark blotch } \\
\text { behind gill opening, followed } \\
\text { by a series of small spots along } \\
\text { flanks in immature ones. These } \\
\text { spots gradually disappear in } \\
\text { large adults. Fins hyaline }\end{array}$ & $\begin{array}{l}\text { Body silvery; a diffuse dark blotch } \\
\text { behind gill-opening. Fins hyaline }\end{array}$ \\
\hline
\end{tabular}

(Source-Bhaumik et al. 2013) 
Int.J.Curr.Res.Aca.Rev.2016; 4(6): 22-38

Table.2 Distribution of Hilsa shad (Tenualosa ilisha)

Country

Names of rivers/lakes

Bangladesh

Principal rivers

The Meghna, the Padma, the Jamuna and the Brahmaputra

Major rivers

The Sibsa, the Baleswari, the Pasur, the Rupsa, the Madhumati, the Kocha, the Lohalia, the Tetulia, the Biskhali, the Buriswar, the Karnaphuli, the Feni, the Naaf, the Kharkhana, the Arial Khan, the Khairabad, the Muhuri, the Surma, the Halda, the Kushiyara, the Matamuhuri, and the Maheskhali Channel.

Minor rivers

The Sangu, the Baral, the Atai-Nabaganga, the Kobadak, the Chitra, the Bhairab, the Betna, the Kumar, the Little Feni, the Selonia, the Mongla, the Ilisha, the Ghuaisakhali, the Bhadra, the Khulpetua, and the Kaliganga

India (West Coast)

The Narbada, the Tapti, the Purna, the Ulhas, the Savitri, the Kali and the Vembanad

India (East Coast)

The Hoogly-Bhagirathi, the Godavari, , the Cauvery, the Krishna, the Mahanadi, the Ganga and its tributaries, the Padma, the Brahmaputra and the Barak including smaller rivers namely Korayar, Pamaniyar, Vellar, Palar, Pennar, Manneru and Uppeteru, and the Chilika Lake.

Iraq The Shatt-al-Arab, the Tigris, the Euphrates and the Lake Hammar

Iran The Shatt-al-Arab

Pakistan The Sindh (Indus), the Jhelum and the Ravi

Myanmar The Irrawaddy, the Naaf and the Sittang

(Source, Pillay \& Rosa 1963; FRSS 1990, Rahman 2001 and FishBase 2012, Rahman et al.,2012) 
Int.J.Curr.Res.Aca.Rev.2016; 4(6): 22-38

Figure.1 Commecial species of Hilsa .

(A) Tenualosa ilisha (B) Tenualosa toli (C) Hilsa kelee
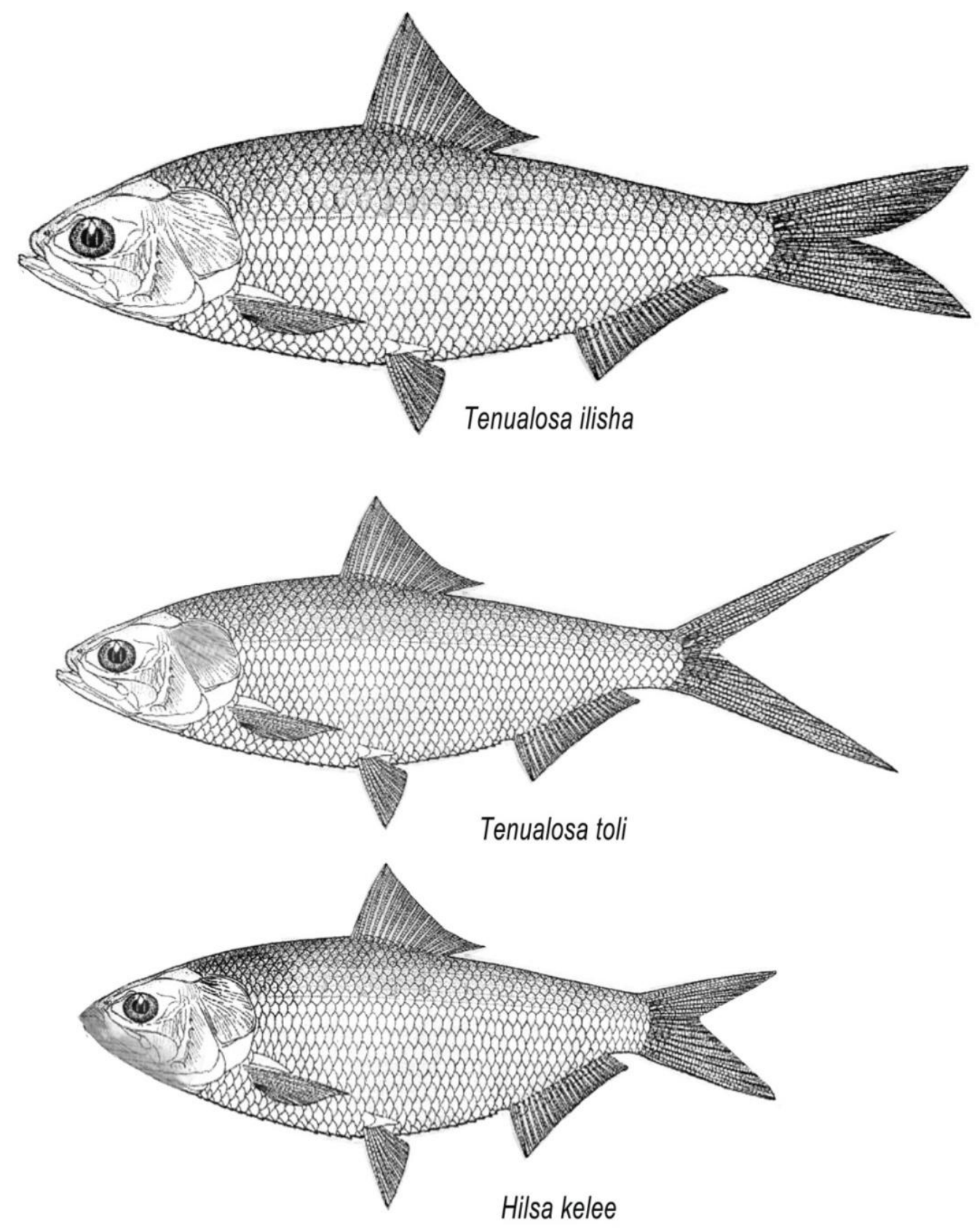


\section{Figure.2 Distribution of Hilsa shad (Tenualosa ilisha)}

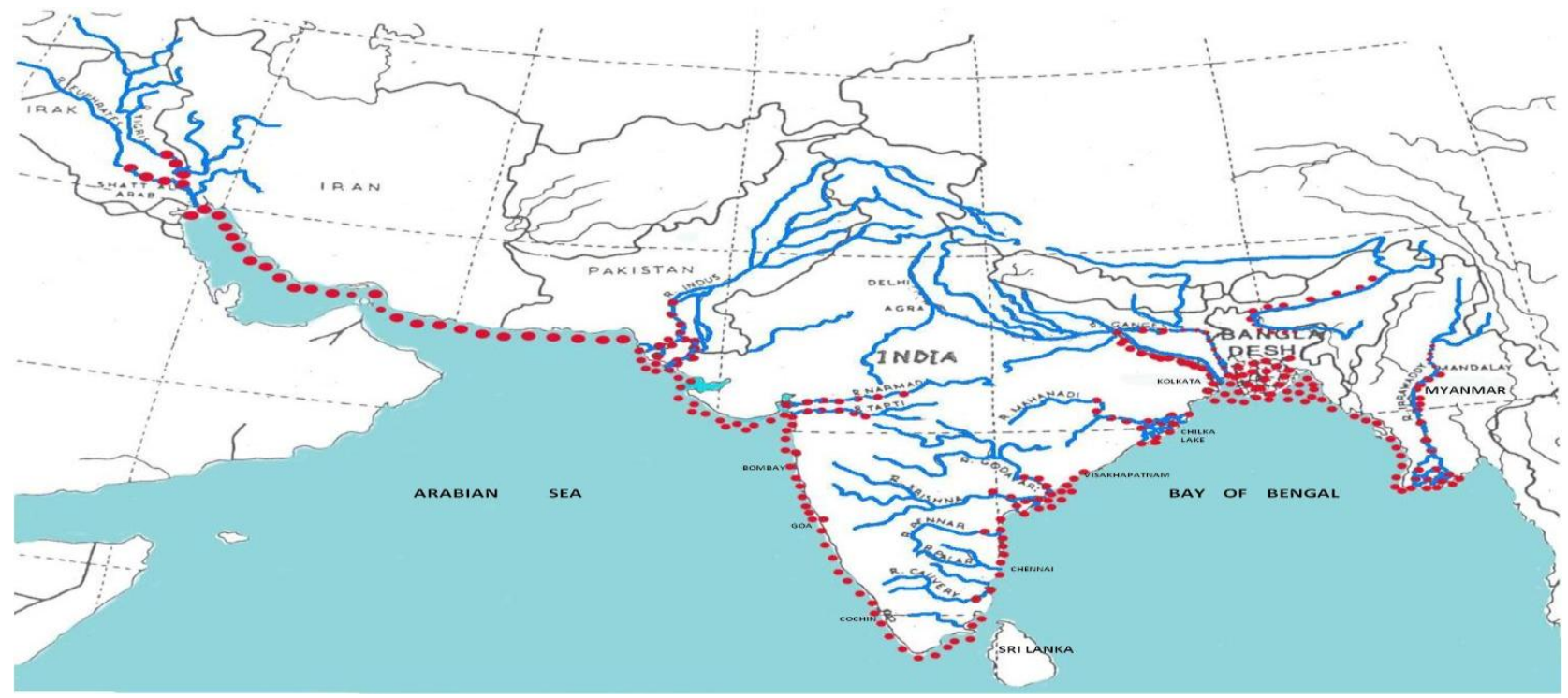

This is in agreement with the study of Milton and Chenery (2001) that used otolith microchemistry to study the stock structure of Hilsa and concluded that there was extensive movement and mixing of Hilsa throughout the Bangladesh, and therefore, the population should be considered and managed as single stock. Genetic and otolith data both showed that Hilsa from India and Myanmar were not significantly different from the fish collected from coastal areas of Bangladesh, and suggest that Hilsa in the Bay of Bengal were a single stock. On the other hand, like allozyme studies, the otolith chemistry method also found differences between the Hilsa of Bangladesh and Kuwait and between Bangladesh and Indonesia.

Shifat et al. (2003) applying RAPD analyzed the genetic variation of Hilsa from the rivers of Padma and Meghna in Bangladesh. The individuals of two river stocks were grouped into two clusters in the dendrogram assuming two different spawning stocks or races of Hilsa shad in two major rivers of Bangladesh. In a preliminary study in Bangladesh, Ahmed et al. (2004) analysed genetic structure of three populations of Hilsa, such as Chandpur (Meghna), Kuwakata (Esturine water) and Cox's Bazar (Bay of Bengal) using RFLP of mitochondrial DNA and observed a high level of polymorphic haplotypes (mean 0.958 ) in the three populations.

Similarly, Mozumdar and Alam (2009) in Bangladesh examined genetic variability and divergence in two riverine (Meghna and Jamuna), two esturine (Kuwakata and Sundarbans) and one Marine (Cox's Bazar) populations of Tenualosa ilisha and reported high levels of haplotype (0.882-0.967) and gene diversity (0.343-0.569) indicating high value of genetic variation within and significant differentiations among the populations of Hilsa.

In Pakistan only one homogenous population of Hilsa ascends the river Indus (Qureshi, 1968). Jarfi et al. (2008) in Iran studied population generic structure of Hilsa in Khouzestan waters including Karoon, Arvandrood and Bahmanshir rivers as well as Persian Gulf using RAPD technique. The study revealed that four samples belonged to 
two groups: one comprising the Karoon river and Persian Gulf and the other comprising Arvandrood and Bahmanshir rivers supporting the hypothesis that there are Iranian and Iraqi populations of the species: the fish from Persian Gulf migrate to the river Karoon in Iran and other populations migrate to the rivers Tigris and Euphrates in Iraq for spawning.

Behera et al., 2015 analyzed Hilsa samples collected from three different sites namely Farakka, Lalgola and Hooghly Ghat from the river Hooghly-Bhagirathi (Bay of Bengal origin) and two sites namely Naupada and Ukai reservoir from the river Tapti, India (Arabian Sea origin) to unravel the structuring and genetic diversity of the population of Hilsa using mitochondrial DNA Cytochrome $b$ gene sequence analysis. Phylogenetic analysis revealed that the Hilsa from Bay of Bengal origin and Arabian Sea origin formed two distinct different clusters.

The study revealed genetic differentiation in Tenualosa ilisha population of the collected samples of Bay of Bengal origin and Arabian Sea origin indicating two different stocks. However, this study contradicted the study of Brahmane et al., 2008 whereas it is in conformity with the study of Salini et al., 2004. In the study, the investigators have observed confirmed differences within the populations of the rivers between HooghlyBhagirathi (3 halotypes) of Bay of Bengal origin and the river Tapti (2 halotypes) of Arabian Sea origin.

\section{Conclusion}

Hilsa possesses wide trans-boundary countries distribution in the Bay of Bengal Sea region and it warrants efforts from all the Hilsa producing member countries towards initiation of joint investigations to unravel the stock or race of Hilsa population in their respective water bodies vis a vis implementation of conservation measures of its natural stock and responsible exploitation of the resource. It should not exceed the MSY level so as to develop sustainable Hilsa fisheries in the river-estuarine systems of the respective countries. Wanton destruction of juveniles and capture of Hilsa brooders should strictly be prohibited. Hence, strict conservation measures are warranted for improvement of Hilsa fisheries in the Bay of Bengal region.

\section{References}

Ahmed, Q.J. 1961. Study of vertebral column of Hilsa with reference to its racial investigation. Agriculture Pakistan, 12: 65-76.

Ahmed, A.S.I., Islam, M.S., Azam, M.S., Rahman, M.M. and Alam, M.S. 2004. RELP analysis of the mtDNA D-Ioop region in Hilsa shad (Tenualosa ilisha) population from Bangladesh. Indian J. Fish., 51(1): 25-31.

Behera, B.K., Singh, N.S., Paria, P., Sahoo, A.K., Panda, D., Meena, D.K., Das, P., Pakrashi, S., Biswas, D.K. and Sharma, A.P. 2015. Population genetic structure of Indian shad, Tenualosa ilisha inferred from variation in mitochondrial DNA sequences, $J$. Environ. Biol., 36(5): 1193-1197.

Bhaumik, U., Naskar, M. and Sharma, A.P. 2011. Size distribution, length-weight relationship and sex ratio of the Hilsa (Tenualosa ilisha) in the Hooghly estuarine system. J. Inland Fish. Soc. India, 43(2): 1-5.

Bhaumik, U., Sharma, A.P. 2012. Present Status of Hilsa in Hooghly-Bhagirathi river. CIFRI Bulletin No. 179: 42 pp.

Bhaumik, Utpal, Mukhopadhyay, M.K, Shrivastava, N.P., Mukherji, C.N., Mitra, A., Haldar, T.K., Mandi, R.C., Barui, A., Bose, Sritama. and Roshith, 
C.M. 2013. Distribution pattern of Hilsa in the Tapti estuary of West coast of India, Environ. Ecol.

Brahmane, M.P., Das, M., Sinha, Sugunan, V.V., Mukherjee, A., Singh, S.N., Prakash, S., Marya, P., Hajra, A. 2006, Use of RAPD fingerprinting for delineating populations of hilsa shad Tenualosa ilisha. Genet. Mol. Res., 5: 643-652.

Brahmane, M.P. 2008. Population structure of tropical shad, Tenualosa ilisha (Ham.) using mitrocondial DNA cytocrome $b$ gene neucleotide sequences. Unpublished Ph.D. Thesis, Kalyani University.

Dahle, G., Rahman, M. and Eriksen, A.G., 1998. RAPD fingerprinting used for discriminating among three populations of hilsa shad (Tenualosa ilisha). Fisheries Res., 32: 263-269.

Das, N.N., Nishida, T., Azad, S.A., Islam, M.S., Hossain, M., and Huq, Q.M., 1987. Hilsa fishery in Bangladesh in 1985-1986. In BOBP, Hilsa Investigations in Bangladesh. Bay of Bengal Program, Colombo, Sri Lanka. BOBP/REP/36: 96-109 pp.

Day, F., 1873. Report on the Sea Fish and Fisherles of India and Burma. Calcutta: 24-25.

Dutt, S., 1966. The Indlan shad, Hilsa ilisha (Ham.) in the sea. Current Sci., 35(13): 329-330.

EOL. 2012. Encyclopedia of life. World Wide Web electronic database. Retrieved in August 2012 from www.eol.org?.

Fischer, W., Whitehead, P.J.P. 1974. FAO species identification sheets for fishery purposes. Eastern Indian Ocean (fishing area 57) and Western Central Pacific (fishing area 71). Volume 1.FAO, Rome, Italy.

FishBase. 2012. FishBase, World Wide Web electronic database. Retrieved in
August

2012from

http://www.fishbase.org.

FRSS. 1990. Fisheries Resources Survey System. Fish Catch Statistics of Bangladesh, 1988-89.Annual report of the Directorate of Fisheries, Dhaka, Bangladesh. 43 pp.

Ghosh, A.N. 1967. Observations on the Hilsa fisheries of the river Jamuna during the years 195-1962 at Allahabad, J. Zool. Soc., 17(1\&2); 135-149.

Ghosh, A.N., Nangpal. 1968. On the winter breeding of Hilsa ilisha (Ham.) in the Ganga river system. Proc. Indo. Pacif. Fish. Coun., 13: 132-142.

Ghosh, A.N., Battacharya, R.K. and Rao, K.V. 1968. On the identification of the sub-population of Hilsa ilisha (Ham.) in the Gangetic system with a note on their distribution. Proc. Nat. Acad. Sci, India, 34: 44-57.

Gupta, R.A. 1987. Status and dynamics of hilsa (Hilsa ilisha) in the Hooghly estuarine system, West Bengal, India. Contributions to tropical fish stock assessment in India. CompendiumFAO/DANIDA/ICAR National Followup Training course on Fish Stock Assessment; 102-114 pp.

Hora, S.L. (1938), A preliminary notes on the spawning grounds and bionomics of the so-called Indian shad, Hilsa ilisha (Ham.), in the river Ganges. Rec. Indian Mus., 40: 147-158.

Hora. S.L. 1940. Dams and the problems of migratory fishes. Curr. Sci., 9: 406407.

Hora, S.L. 1942. The effects of dams on the migration of Hilsa fish in Indian waters. Curr. Sci., 11: 470-471.

Hora, S.L., Nair, K.K. 1940a. The jatka fish of Eastern Bengal and its significance in the fishery of the so-called Indian shad, Hilsa ilisha (Ham.). Rec. Indian Mus., 42: 553-565. 
Hora, S.L. and Nair, K.K. (1940b) Further observations on the bionomics and fishery of theIndian shad Hilsa ilisha (Ham.) in Bengal waters. Records of Indian Museum, 42: 35-40.

Hussain, M.G., Salini, J.P., Islam, M.S. and Mazid, M.A. 1998. Genetic structure of Hilsa shad populations: preliminary results using starch gel allozymes. In: Mazid, M.A. and Blaber, S.J.M..Hilsa fisheries research in Bangladesh. Proc. BFRI/ACIAR/CSIRO workshop, 3-4 March, 1998, Dhaka, Bangladesh, 37$42 \mathrm{pp}$.

Jafri, S.I.H. 1988. Biology and fishery of river shad (Palla) - A review. Pakistan J. Agric. Res., 9(2): 252-263.

Jafri, S.I.H. 1994. A review of the blology and flshery of rlver shad, Tenualosa ilisha (Ham.). Proc. National Seminar on fishes policy and planning, Pakistan: 301-315.

Jafri, S.I.H, Narejo, T.N., Bloch, W.A. and Sahato, G.A. 1999. Studies on the land locked population of Palla, Tenualosa ilisha from Keenjhar lake (Sindh), Pakistan, Pakistan J. Zool., 31(4): 347-350.

Jenkins, J.T. 1940. Hilsa investigations in Bengal. Curr. Sci., 9(5): 241-242.

Jhingran, V.G., A.V. Natarajan. 1969. A study of the fisheries and fish populations of the Chilka Lake during the period 1957-65. J. Indian Fish. Soc, 1: 49-126.

Job, T.J. 1942. Hilsa investigations in Bengal Waters. Sci. Culture, 7(9): 427-429.

Lal, K., Kuldeep, Kumar, D., Srivastava Satish, Mukherjee, A., Mohindra Vindya, Prakash Shree, Sinha, M., Ponnaiah, A.G. 2004. Genetic variation in Hilsa shad (Tenualosa ilisha) population in River Ganga, Indian J. Fish, 51(1): 33-42 p.

Melvin, G.D. 1984. Investigation of the hilsa fishery of Bangladesh, 1983. A report prepared for the Fishery Advisory Service, Phase II. Food and Agriculture organization of the United Nations, Rome, Italy. Project Number, FAO. FI:DP/BGD/81/034, Field Document 5: 56p.

Mazumder, K.K., Alam, M.S. 2009. High levels of genetic variability and differences in hilsa shad, Tenualosa ilisha (Clupeidae, Clupeiformes) populations revealed by PCR-RFLP analysis of the mitochondrial DNA Dloop region. Genet. Mol. Biol., 32: 190-196.

Mojumdar, C.H. 1939. Foreshore fishing in the eastern parts of the Bay of Bengal, Science and Culture, 5(4): 219.

Milton, D.A., S.R. Chenery. 2001. Can otolith chemistry detect the population structure of the shad Hilsa, Tenualosa ilisha? Comparison with the results of genetic and morphological studies. Mar. Ecol. Prog. Ser., 222: 239-251.

Naidu, M.R. 1939. Report on survey of the Fisheries of Bengal, Calcutta.

Nei, M. 1987. Molecular evolutionary genetics, University Press, New York; 176-207 pp.

Pillay, S.R., Rosa, H. 1963. Synopsis of biological data on Hilsa, Hilsa ilisha (Ham.) 1822.FAO Fisheries Synopsis, 25, $61 \mathrm{pp}$.

Pillay, T.V.R. 1955. Morphological and serological chararcters of the Hilsa, Hilsa ilisha (Ham.) with special reference to racial investigations. $J$. Asiatic Soc., 20: 69-74.

Pillay, T.V.R. 1958. Biology of the Hilsa, Hilsa ilisha (Ham.) of the river Hooghly. Indian J. Fisheries, 5: 201257.

Pillay, T.V.R. 1952. A preliminary biometric study of certain populations of hilsa, Hilsa ilisa (Ham.). 
Proceedings of the Indo- Pacific Fisheries Council, 4(2): 181-193.

Pillay, T. V. R. 1954. Investigations of the racial characteristics and Biology of the hilsa of the River Hooghly. Proceedings of the Indo- pacific Fisheries Council 5(2\&3): 143 (Abstract).

Pillay, T.V.R. 1955. Morphological and serological characters of the hilsa. Hilsa ilisa (Ham.) with special reference to racial investigations. $J$. Asiatic Soc. Sci., 20(1): 69-74.

Pillay, T.V.R. 1957. A morphometric study of the populations of hilsa, Hilsa ilisa (Ham.) of the river Hooghly and the Chilka Lake. Indian J. Fisheries, 4(2): 344-386.

Pillay, T.V.R., K.K. Ghosh. 1962. The bagnet fishery of the Hooghly-Matlah estuarine system (West Bengal). Indian J. Fisheries, A 9(1) : 71-99.

Pillay, T.V.R., Pillay, S.R., Ghosh, K.K. 1963. Comparative study of the population of Hilsa, Hilsa ilisha (Ham.) in Indian waters. Proceeding of the Indo-Pacific Fisheries Council, 10, 62-104.

Rao, M.B. 1969. Some observations on the juveniles of Hilsa ilisha (Ham.)(Pices: Clupeidae) from Godavari Estuary. $J$. Bombay Natural Historical Soc., 66(1): 116-131.

Raja, B.T.A. 1985. A review of the biology and fisheries of Hilsa ilisha in the upper Bay of Bengal. Proceedings of the Marine Fisheries Resourse Management. Bay of Bengal, Colombo, Sri Lanka. FAO/UNDP BOBP/WP/37: 66 pp.

Quddus, M.M.A. 1982. Two types of Hilsa ilisha and their population biology from Bangladesh waters. Ph D. thesis, University of Tokyo, Japan, 180pp.

Quddus, M.M.A., Shimizu, M., and Nose, Y. 1984. Meristic and morphometric differences between two type of Hilsa ilisha in Bangladesh waters. Bull. Japanese Soc. Sci. Fisheries, 50: 4349.

Quereshi, M.R. 1968. Hilsa fishery in East Pakistan. Pakistan J. Scientific and Industrial Res., 11: 95-103.

Rahman, M.A., M.S. Miah, M.J. Rahman, G.C. Haldar and M.A. Mazid. 1997. Application of biometric and electrophoretic methods for the stock discrimination of Hilsa (Tenualosa ilisha) in Bangladesh waters. Indian J. Animal Sci., 67(11): 1024-1027.

Rahman, M. 1997. Studies on population structure of shad in Bangladesh waters with emphasis on population genetics of Hilsa shad (Tenualosa ilisha). Ph D thesis, Dep. Fish. and Mar. Biol., Univ. Bergen, Norway.

Rahman, M.J., Moula, G. 1992. Management-oriented research on the hilsa fisheries of Bangladesh. NAGA, 15: 34-35.

Rahman, M., Naevdal, G. 2000. Population genetic studies of Hilsa shad, Tenualosa ilisha (Hamilton), in Bangladesh waters: evidence for the existence of separate gene pools. Fisheries Management and Ecol., 7: 401-411.

Rahman, M.J. 2001. Population biology and management of the Hilsa shad (Tenualosa ilisha) in Bangladesh. Ph.D. Thesis. The University of Hull, England. 253 pp.

Rahman, M.A., Miah, M.S., Rahman, M.J., Haldar, G.C. and Mazid, M.A. 1997. Application of biometric and electrophoretic methods for the stock discrimination of hilsa (Tenualosa ilisha) in Bangladesh waters. Indian J. Animal Sci., 67: 1024-1027.

Rahman, M., Jalilur, Rahman, M., Anisur and Utpal Bhaumik, M. Anisur. 2012. Biology and Ecology of Hilsa Shad, 
Tenualosa ilisha (Ham.),

Compendium, Regional Workshop on Hilsa potentials for aquaculture, September 16-17, 2012, Dhaka, Bangladesh.

Ramakrishnaiah, M. 1972. Biology of Hilsa ilisha (Hamilton) from the Chilka lake with an account on its racial status. Indian J. Fish., 19: 35-53.

Shafi, M., M.M.A. Quddus and H. Hossain 1977. A morphology study of the population of Hilsa ilisha (HamiltonBuchanan) from the river Meghna. Ibid., Abstracts, A-40.

Salini, J.P., D.A. Milton, M.J. Rahman and M.G. Hussain. 2004. Allozyme and morphologicalvariation throughout the geographic range of the tropical shad, Hilsa Tenualosa ilisha. Fisheries Res., 66: 53-69.

Shad Foundation. 1998. The World Wide Web version of the Shad Foundation.
Shifat, R., Begum, A., Khan, H. 2003. Use of RAPD fingerprinting for discriminating two populations of Hilsa shad (Tenualosa ilisha) from inland rivers of Bangladesh, $J$. Biochem. Mol. Biol., 36: 462-467. URL:http://www.cqs.washington.edu/ $\sim$ hinrich/shad/descriptions/tenualosa/il ish.html.

Sujansinghani, K.H. 1957. Growth of the Indian shad, Hilsa ilisha (Ham.) in the tidal stretches of the Hooghly. Indian J. Fisheries, 4(2): 315-335.

Whitehead, P.J.P. 1985. Clupeoid fishes of the world (suborder Clupeoidei) an annotated and illustrated catalogue of the herrings, sardines, pilchards, sprats, shads, anchovies and wolfherring. Part I. Chirocentridae, Clupeidae and Prisgasteridae. FAO Fisheries Synopsis, 7: 303 pp.

\section{How to cite this article:}

Utpal Bhaumik. 2016. Stock Profile of Hilsa Shad Population in Bay of Bengal Region- A Review. Int.J.Curr.Res.Aca.Rev.4(6): 22-38. doi: http://dx.doi.org/10.20546/ijcrar.2016.406.004 